Alovsat G. Aliyev' ${ }^{1}$ Roza O. Shahverdiyeva ${ }^{2}$

DOI: 10.25045/jpis.v08.i1.07

${ }^{1,2}$ Institute of Information Technology ANAS, Baku, Azerbaijan

19alovsat_qaraca@mail.ru, ${ }^{2}$ shahverdiyevar@gmail.com

\title{
SCIENTIFIC ANDMETHODOLOGICAL FOUNDATIONS OF ESTABLISHING OF COMPOSITE INDICATOR SYSTEM FOR COMPARATIVE ASSESSMENT OF ACTIVITIES OF TECHNOPARKS
}

The paper reviews the issues of comparative assessment of technoparks' activities as an innovative structure. The foundations of scientific and methodological development of composite indicator system are explored, in this regard. The stages of development of composite indicator system, requirements posed to them, their generalized composition and content are shown. Main group of indicators characterizing the activity of technoparks are defined. The study presents the stages of successive formation of indicators and variables upon which main indices and subindices of technoparks depend.

Keywords: innovative economy, special economic zone, innovative technopark, innovation infrastructure, system of indicators, technopark composite index, subindex, effective management, creative outcome.

\section{Introduction}

The economic situation in any country is related to the development of science and technologies and their implementation. Modern innovative technologies facilitate the prosperity as a guarantor of stable economic growth and to improve the welfare of society. In recent years, adopted economic reforms have created new opportunities in fostering innovative activity. On the other hand, new problems have emerged in regulation of the sphere of innovation. These are the issues related to the study and evaluation of the efficiency of innovative activity in socio-economic system, as well as the development of appropriate mechanisms and tools for its improvement.

The formation of innovation policy in economic development of advanced economies is considered among the most important issues. In innovation-based economies, large costs related to the conduction of fundamental and applicative scientific research works are borne by one organization, whereas the benefits are reaped by other enterprises. Hence, the analysis, evaluation and regulation of innovative processes have become one of the substantial and necessary issues. In such case, it is important to assess the importance of innovations, innovative processes and technopark structures for the economy and society, as well as the efficiency and outcomes of their complex activity.

Several designed programs and decrees have been adopted at state level regarding the economic development of Azerbaijan. According to these documents, it is envisaged to establish innovation structures, in other words, innovation centers, technological business incubators and technoparks. Considering the importance of technoparks in economic development, the Law on "Special economic zones" [1] has facilitated the opportunity to regulate the relations regarding the establishment and management of appropriate zones and determine the rules of organization of entrepreneurship activity. Moreover, the development of infrastructure on innovation activity, including the expansion of technoparks, technological centers and business incubators network was posed as one of the tasks in the "National Strategy for information society development in the Republic of Azerbaijan for 2014-2020 years" [2]. All these factors necessitate accelerating the process of formation of knowledge and innovation-based economy and the establishment of technoparks as a foundation of innovation infrastructure [3,4]. This process, in turn, urges the complex evaluation of the activity of technoparks in a separate and complex manner as an important matter. Detailed study and the analysis of theoretical and methodological foundations of this process and development of appropriate recommendations and guidelines are of special importance. 


\section{Problem statement}

Development of theoretical and methodological foundations and guidelines on separate evaluation of the activity of innovation structures, including technoparks, and its complex evaluation in comparison with other technoparks, as well as the development of the system of indicators and criteria constitutes the essence and subject of the considered problem.

The primary goal in the presented article is to analyze the current situation regarding the complex approach to individual evaluation of the activity of elements of innovation infrastructure and a comparative assessment with other technoparks, and develop guidelines on establishing the system of indicators in corresponding field. For this purpose, it is necessary to generalize the requirements on the formation of indicators system allowing implementing the indicated evaluation and developing methodological base and scientific-theoretical foundations of this system.

Moreover, the composition and content of indicators system must also be determined. Since indicators system is represented in various levels and groups, methods allowing the determination of relevant evaluation guidelines, and weight or impact coefficients for each indicator needs to be developed. Principally, such evaluation methods are required to be independently applicable, and the development of their computer models should be feasible. At the same time, information provision issues necessary for the assessment of indicators must be timely investigated and solved.

\section{Stages of building the composite indicators system and requirements set on them}

As known, wide range of scientific research have been conducted regarding the development of indicators system on independent and comparative evaluation of the performance of technoparks [5]. Although numerous scientific articles have been published on this field, in general, the complex development of indicators system regarding the activity of technoparks is rarely available. The authors of those works have suggested incomplete indicator groups only. This confirms that, the issue of development indicator system on the evaluation of technoparks' activity is among the topical and important issues.

Overall, the main reason for wide use of numerous indicators system developed for evaluating modern development period of the society and economy is that those systems are capable of providing a clear comment of the information obtained as a result of the analysis of socio-economic events. Composite indicators are also widely used in evaluation system in recent years [5].

Composite indicators are useful tools for evaluation, analysis and comparison of the level of development of the society and economy. In accordance with the official explanation of International Labor Organization (ILO), composite indicators are generated as a result of comprising separate indicators measured on the basis of multidimensional criteria in a unified index. The construction of composite indicators and indices is a daunting task, and entails numerous stages, which requires in-depth investigations. In order to provide the foundation for choosing and unifying the variables included in composite indicators, theoretical foundations must be developed. Summation and weights of indicators must be carried out in accordance with theoretical foundations [5]. Variables must be selected on the basis analytical stability, measurability, comprehensiveness and the presence of mutual corelations among these variables.

The research system must shed light on the general structure of variables, evaluation of feasibility of database and methodology selection. Various approaches must be considered for conditional calculation of missing data.

Indicators must be normalized in order to make the comparison of indicators possible. According to the importance of each indicator, appropriate weight must be calculated for each and summation must be done in order to obtain final index, based on a developed methodology.

It is necessary to conduct appropriate reliability tests of composite indicator, from the point of view of mechanisms of including and excluding discrete indicators, mechanisms of normalization, calculation of missing data and choosing weights. 
Composite indicators must be transparent and dividable into indicators and quantities included in this index. An endeavor is necessary to reveal relationships between composite indicators and other declared variables, drawing upon the regression analysis [6-8]. Composite indices must be visualized and presented with various methods. Surely, indicated stages are conditional and can be subject to particular changes depending on research subject.

\section{Composition and content of composite indicators system}

Composite index enables to indirectly assess the efficiency of technoparks' activity. It allows to speculate about the role and share of technoparks in the society. In order to build a composite index, the values of below mentioned indicators with conditional signs and names are suggested as a basis (Figure 1)

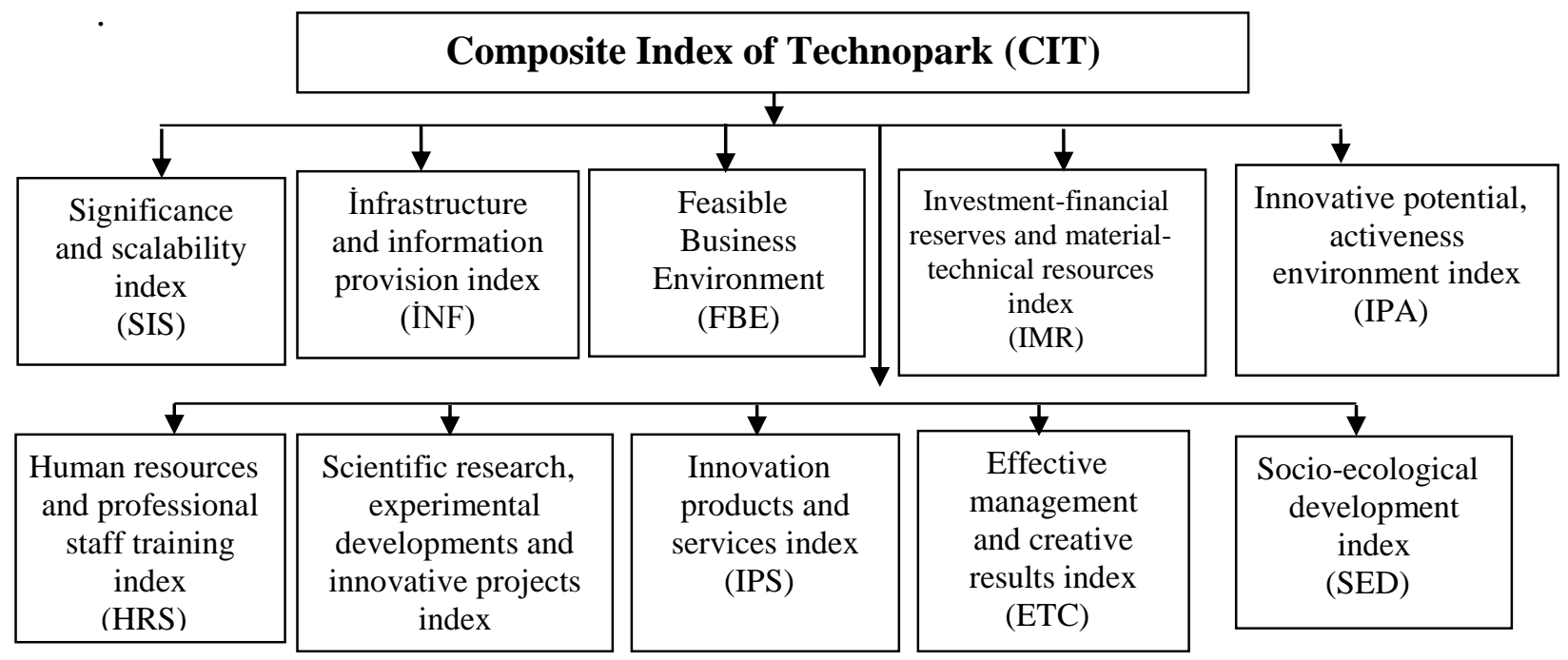

Figure 1. Main index groups characterizing technoparks' activity

The structure of composite indicator system (CIS) is suggested in multi-level form. The top level reflects all lower levels in an integrative manner, and a characterizing parameter is referred as composite index of technopark (CIT) (Figure 2).

Composite index is built as a result of assessment, and it occupies a leading position in comparative analysis. That is, as a result of such assessment, technoparks are given corresponding rating. The value of composite index can vary within $[0,100]$ interval.

Thus, CIT calculation can be functionally indicated as below:

$$
C I T=F I(S I S, I N F, F B E, I M R, I P A, H R S, S E I, I P S, E T C, S E D) \text {. }
$$

Where, FI denotes the functional form of dependence of composite index on other indices, brief information on the essence and content of main indices building CIT are given in following sections. 


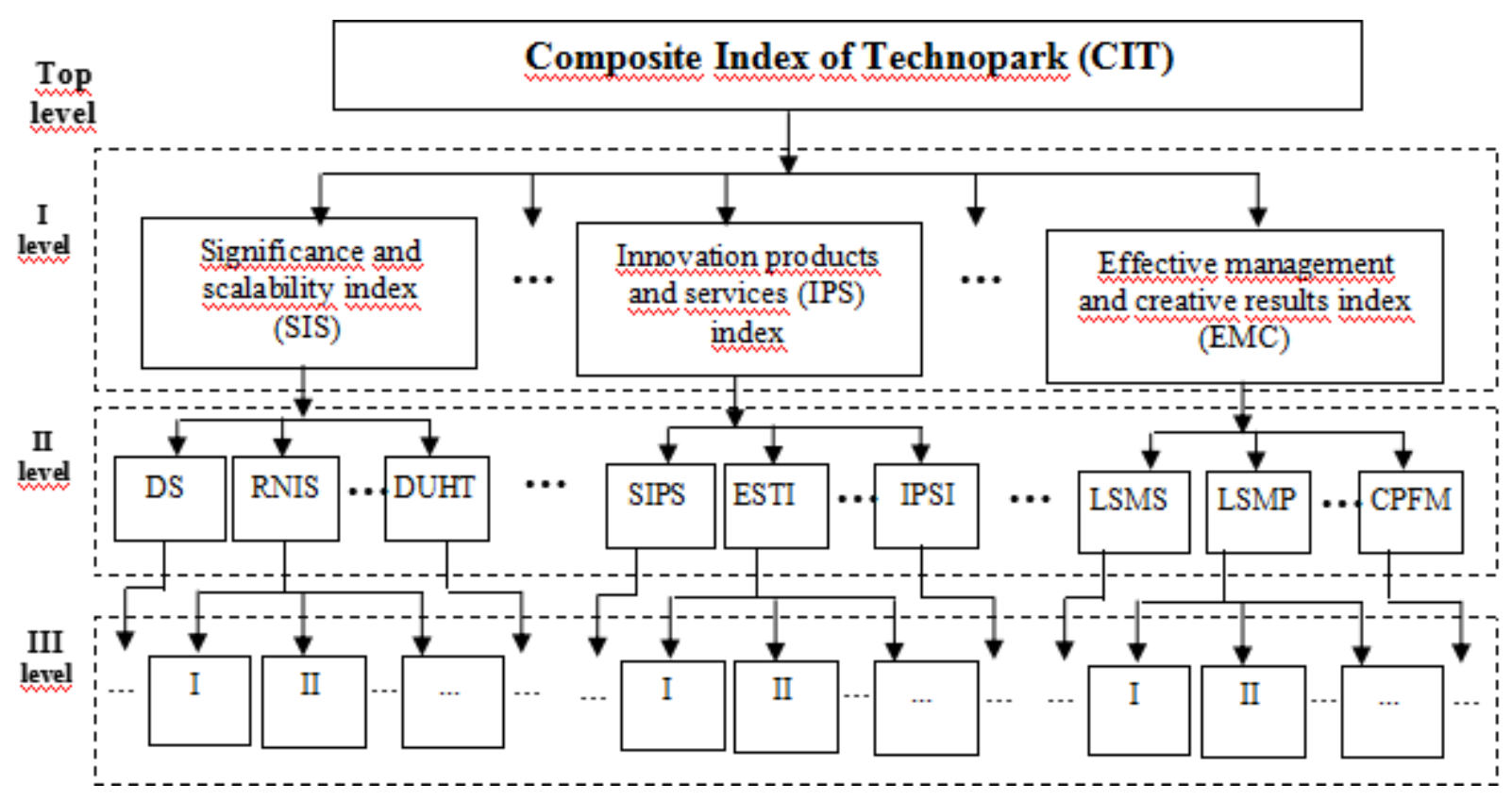

Figure 2. Hierarchical structure of technoparks' indices and indicators

\section{Significance and scalability (SIS) index}

This index characterizes the degree of importance of building technoparks, organization of their activity and a role played in socio-economic life of the region of location and the level of participation in the sphere of specialization or economic sector. Moreover, it also shows the level of favorableness of the area covered by technopark and the scale of the area covered. As a result, this index allows determining the impact of technopark in the economy and society.

Some subindex groups directly or indirectly affect the building of index characterizing the importance and scale of technopark. In our case, we have included 12 subindices into the group. Each subindex individually affects the building of SIS index within [0, 100] interval. The methodology of procedure of formation and assessment of weight coefficients, as well as SIS index is carried out with expert methodology based on fuzzy approach. The values of subindices and weighted coefficients of indicators, correspondingly affecting those subindices, can be determined with that method at later stage.

We suggest to include the following subindices in the composition of importance and scale index: compliance of spheres of activity and specialization directions with state programs (SSSP), degree of scale (DS), role and importance in formation of national innovation system (RNIS), impact and importance on formation of knowledge economy (IFKE), level of participation in export-oriented and knowledge-intensive goods production (EOKI), level of participation in competitive goods production (CGP), level of assignment (LAS), priviledgeness and statusness (PS), effectiveness of property relations (EPR), area favorableness (ARFA), comprehensiveness of fundamental, applicative, empirical and innovative research (CFAEI), level of building of various links on development and use of high technologies (DUHT).

Hence, given the symbols denoted above, the building of MIG index and the functional dependence of subindices constituting this index can be given as below:

$$
M I G=F_{1}(S S S P, D S, R N I S, I F K E, E O K I, C G P, L A S, P S, E P R, A R F A, C F A E I, D U H T)
$$

\section{Infrastructure and information provision (INF) index}

INF index indicating the level of development of technoparks infrastructure and information provision characterizes the level of organization of access opportunities to necessary software bases, e-libraries and scientific foundations on information provision activity and the provision of various 
services. INF index also reflects the level of presence of extensive infrastructure and comprehensive information provision base for complex management of technoparks' activity.

Technopark infrastructure is constituted of land areas, buildings, non-residential areas, roads and transportation and set of facilities providing social, cultural, public catering, administrative, engineering-communication maintenance and other activities. Engineering-communication maintenance of technoparks is supplied with gas, heating, communication, electricity, water and other. tools and devices necessary for exploiting infrastructure facilities [9-11].

The infrastructure of technoparks is constituted of the sum of mutually linked structures and objects, as well as specific system of the institutions mutually linked for the activity of various economic subjects. It consists of the provision of building comprehensive relations with the structures engaged in innovation, business, finance, production, marketing activity and intellectual property protection in technopark's activity.

The building of secure information provision of technoparks by using innovative technologies in management of its activity is one of the important conditions of facilitating innovation activity.

Following subindices can be included in INF Index: level of building links with innovation and business structures (BIBS); level of links with financial-credit and insurance structure (FCIS); level of building relations with production infrastructure (BRPI); level of building links with marketing structures (LBMS); level of opportunities of using and developing modern information technologies (UDMI); level of information protection and security (LIPS); level of automatization of work places (LAWP); level of provision with mobile communication tools (PMCT); level of organization of links with ICT and Internet services (ICTI); level of organization of links with intellectual property protection structures (LIPP); level of favorableness of transport infrastructure (LFTI); level of provision with material-technical and municipal resources (LPMM), level of organization of access possibilities to e-libraries and scientific bases (ELSB); level of favorableness of socio-ecological infrastructure (FSEI).

Given the above-mentioned indications, the functional form $\left(\mathrm{F}_{2}\right)$ of INF index can be expressed as follows:

$$
\begin{gathered}
I N F=F_{2}(B I B S, F C I S, \text { BRPI, LBMI, UDMI, LIPS, LAWP, PMCT, ICTI, LIPP, LFTI, } \\
\text { LPMM, ELSB, FSEI) }
\end{gathered}
$$

Here, $F_{2}$ expresses the functional dependence form of INF on building subindices.

\section{Favorable business environment (FBE) index}

This index reflects the favorableness of the environment necessary for developing entrepreneurship in techoparks, the effectiveness of institutional structures and mechanisms for business development, the level of legal regulatory environment, and the existing and forecasted situation of business environment according to several necessary characteristics [12].

The status of business environment in technoparks is a leading factor determining the ability of the country to attract foreign investment and develop small and middle enterprises. Growth opportunity of small and middle enterprises is higher in a curcimstances exacerbated with various taxes and regulations. A favorable business environment is the foundation of the fostering strategy of economic development.

Business environment is the presence of opportunities and incentives directed towards the productive investments, generation of job places and activity expansion in technoparks. Political stability, rule of law, macroeconomic situation, trust for the government and the regulatory environment are among other necessary factors significantly affecting the business environment [13, 14].

The presence of favorable business environment in technoparks entails the boost of entrepreneurship development, effective protection of rights of entrepreneurs, growing share of private sector in GDP, the implementation of simplified administrative procedures and transparent 
mechanisms, the integration of the country in world economic system and implementation of joint transnational projects with foreign partners.

Following subindices can be included in the composition of FBE index: effectiveness of the activity of institutional structures (EAIS); formation and improvement of legal framework (FILF); opportunities of business development (OBD); functionality of mechanisms of protection of entrepreneurs' interests (FMPE); level of use of new information and communication tools (UNIC); efficiency of activity environment of small enterprises (EASE); opportunities of building business environment (OBBE); functionality of funds and mechanisms of entrepreneurship development (FMED); level of reliability of business environment (LRBE); sustainability and stability level of political and economic environment (SSPE); level of competitiveness of business environment (LCBE); level of implementation of incessant reforms (LIIF).

Given the above-mentioned indications, functional form $\left(\mathrm{F}_{3}\right)$ of FBE index can be shown as follows:

$$
\begin{gathered}
F B E=F_{3}(E A I S, F I L F, O B D, F M P E, U N I C, E A S E, O B B E, F M E D, L R B I, \\
\text { SSPE, LCBE, LIIF) }
\end{gathered}
$$

\section{Investment-financial reserves and material-technical resources (IMR) index}

This index integratively characterizes the status of financial and investment reserves in technoparks, their effective use, as well as the sustainability and stability of provision with necessary material-technical resources. At the same time, this index characterizes the functionality of mechanisms of user of financial and technical resources necessary for the organization of complex activity of technoparks.

The establishment and organization of the activity of technopark are financed by state budget, and incomes generated by administrative organization and other sources. Financial reserves of technoparks are constituted of the sum of their income and charges. Financial reserves are formed by income of technoparks, budget, innovation fund, depreciation fund, production development fund, attracted resources, insurance payments, profits from financial operations, long-term loans of banks and organizations, payments by companies and organizations supporting them, financial funds of donor organizations, specialized regional funds, specialized funds under international financial organizations and etc.

Financial-investment reserves in technoparks are built in accordance with financial policy and managed by corresponding financial mechanism [15]. The performance of financial mechanism serves to the establishment of financial reserves, their distribution and the efficient use of established financial reserves. Financial mechanisms are constituted of mutually linked elements such as financial methods, normative legal guarantee and information provision. The following are attributed to investment reserves of technoparks: money, bank deposits, loans, shares and other assets, movable property and real estate, appropriately formalized scientific-empirical and other intellectual resources, unpatented technical documentation necessary for the organization of any type of production, sum of technical, technological, commercial and other knowledge ("know-how"), natural resources, rights to use the technology, and other property rights emanating from copyrights..

The primary duties of technical maintenance of technoparks include obtaining technologicalmaterial resources in a most efficient way, complete and timely provision of raw materials and materials for production, to organize the correct storage of technological materials, improve the structure of technical maintenance service, build favorable relations with customers, develop technical maintenance plans and etc [16].

The primary duty of technical maintenance service is to supply high-quality technological and material resources for an enterprise with fewer costs in a timely and complex manner. Technical maintenance organized on efficient and scientific-innovative foundations reduces the prime cost of innovative product, and raises the level of indicators such as labor productivity, quality, profitability and etc. 
Considering the above mentioned cases, it is suggested to include the following subindices to IMR index of technopark: functionality of investment funds and mechanisms (FIFM); level of impact of investment resources structure (IIRS); functionality of mechanisms of attracting investment (FMAI); level of state support for investments (LSSP); level of impact of financial resources structure (IFRS); effective functioning financial-investment structures (EFFS); level of effectiveness of financing mechanisms (LEFM); level of efficiency of investment (LEI); level of meeting demand for material-technical resources (MDMR); functionality of technical maintenance mechanisms (FTMM).

Above presented subindices can be analyzed separately, and it is possible to determine other indicators and variables affecting those subindices. As in previous case, these subindices are defined within $[0,100]$ interval by experts groups.

Therefore, given the above mentioned symbols, the functional designation of IMR index $\left(\mathrm{F}_{4}\right)$ can be expressed as follows:

$$
I M R=F_{4}(F I F M, \text { IIRS, FMAI, LLSP, IFRS, EFFS, LEFM, LEI, MDMR, FTTM) }
$$

\section{Innovative potential, activeness and environment (IPA) index}

IPA index plays an important role in the assessment of the activity of technoparks. Several subindices and indicators are taken into consideration while building it [17]. As can be seen from its name, this index denotes the quantitative characteristics of innovative potential in technoparks and the quality of innovative activity and environment. Innovative potential reflects the readiness and the opportunities for the implementation of innovation issues and programs in technoparks. Innovative potential is built by material and scientific-technical potential, financial-economic resources, organizational resources, human resources, production-technological potential, sociopsychological factors and etc.

The structure of innovative potential is constituted of the unity of mutually linked integral components such resource, internal component and efficiency [18]. Resource component includes technical resources, information resources, financial resources and human resources. Internal component is constituted of the following parts: state support and infrastructure resources. Efficiency component reflects the content of mechanisms of use of indicated technopark resources.

The innovative environment envisages the building of favorable and special innovation environment for the development of all participants and resident companies operating in technoparks.

The building of innovative environment in technoparks can be divided into macro, meso and micro levels. The structure of innovative environment in technopark is constituted of the building favorable internal and external environment for providing innovative development which facilitates the generation and implementation of a new product and technology [19].

Human capital, the support for innovations and technological infrastructure can be attributed to the building of innovation environment structure in technopark. The human capital also covers economic-social composition, labor conditions, incomes, living standard, mobility of labor resources and etc. [20-23].

The support for innovation in technopark is composed of financial-economic and politicoinstitutional provision. Technological infrastructure covers scientific-research, information and consulting maintenance, development of new technologies, use of innovative technologies and production infrastructure.

The primary founding principles of the formation of innovative environment in technoparks include customer-oriented priority directions of generation and application of efficient innovation, the leading role of economic systems in building innovative environment, use of capabilities of innovative potential and staff potential, systematic approach, new management tasks, dynamism, balancing, unification, relative openness, creative attitudes and etc. 
It is suggested to include the following subindices in innovative potential, activeness and environment (IPA) index: level of production potential capabilities (LPPC); level of investment potential (LIPO); level of effect of intellectual potential (LEIP); administrative management and institutional potential (AMIP); organizational innovation potential (OIPO); marketing innovation potential (MIPO); innovative activity potential (IAPO); information sources potential (ISPO); environmental potential (ENPO); level of innovation activity (LOAC); favorableness of innovative environment (FAIE).

Considering the above-mentioned indications, the designation of IPA index can be functionally $\left(F_{5}\right)$ expressed as follows:

$$
I P A=F_{5}(L P P C, L I P O, L E I P, A M I P, O I P O, M I P O, I A P O, I S P O, E N P O, L O A C, F A I E)
$$

\section{Human resources and professional staff training (HRS) index}

This index reflects the current situation on human resources and professional staff training. Human resources employed for achieving the posed goal encompasses the total labor force to be potentially attracted by internal and external resources of technopark and their level of specialization, including all employees from high-rank leadership to law-rank workers.

Overall, in order to achieve the goals of technoparks, it is necessary to employ and purposefully direct the accurately planned, recruited and specialized staff. These activities are among the most important conditions of human resources management [24].

The 3 " $\mathrm{R}$ " principle (right time, right position, and right person) is widely adopted in human resources management. It is very important to recruit experts, remunerate them correspondingly, train, develop and stimulate and motivate them [24].

The functions of human resources management include the structural analysis and planning, selection and placement of human resources, their education and specialization, adaptation, labor remuneration, assessment of work activity, labor motivation and stimulation, labor protection etc.

The process of staff training in technoparks can include the provision of selection and efficient placement of skilled personnel, provision of environment for raising the level of staff professionalism and comprehensive personal development, the staff reserves for high-rank positions and etc.

It is suggested to include the following subindices in HRS index of technopark: effectiveness of the structure an dynamism of innovative staff potential (EISP); level of staff intellectualization (LSIN); quality level of staff resources (QLSR); sustainability level of staff potential (SLSP); level of management of human resources (LMHR); level of socio-cultural and public activity of human resources (SPAH); level of participation in management and decision-making process (PMDP); level of provision of effective work conditions for personnel (PEWC); level of personnel satisfaction (LPES); level of personnel training (LPTR).

Considering the above mentioned symbols, the designation of IPA index can be functionally $\left(F_{6}\right)$ expressed as follows:

$$
H R S=F_{6}(E I S P, L S I N, \text { QLSR, SLSP, LMHR, SPAH, PMDP, PEWC, LPES, LPTR). }
$$

\section{Scientific-research, experimental developments and innovative projects (SEI) index}

This index characterizes all scientific research, empirical, experimental, fundamental and applicative developments starting from the stage of creation of the idea till innovation product and projects in this sector. Scientific-research and empirical developments of technopark are scientific activities successively implemented in order to explore application and research fields for improving scientific knowledge and their application. One of the forms of implementation of such activities is innovative projects. The staff engaged in research and development is comprised of individuals who oriente their creative activities towards services related to improving scientific knowledge, exploring new application fields, as well as the implementation of research and development. 
Innovation projects in technopark are directed towards the successive implementation of the total of mutually related works which provide the creation, production and realization of any innovative product. Innovation project is a system of programs of application of scientific research, empirical-constructor, production, organizational, commercial and other complex measures for achieving the main goals. Innovation project - is a specific form of the organization and management of an innovation process, the result of which is the innovation product [25].

It is suggested to include the following subindices in ETI index of technopark: effectiveness of the structure and dynamics of scientific-research and empirical organizations (ESEO); effectiveness of scientific staff reserves structure (SSRS); level of material-technical base (LMTB); level of financing sources and resource opportunities (FSRO); level of scientificness of innovation (LSIN); effectiveness of the structure and dynamics of innovative projects (ESDI); level of publication of scientific-research (LPSR); level of commercialization of scientific research (LCSR); level of conduction of joint scientific research at international level (CSIL); level of transformation of scientific research to innovation (TSRI).

So, considering the above mentioned indications, the designation of SEI index can be functionally $\left(F_{7}\right)$ expressed as follows:

$$
S E I=F_{7}(E S E O, S S R S, L M T B, F S R O, L S I N, E S D I, L P S R, L C S R, C S I L, T S R I) .
$$

\section{Innovation products and services (IPS) index}

This index encompasses the status of innovation products and services emerging as a result of complex activity of technoparks. It allows us to postulate an opinion on the effective structure and dynamics of innovation products and services, their share in export and import al science and resource intensity. It enables to assess the current situation on marketing programs, the level of commercialization and other realization issues and make some projections for future [26].

Innovation product and service is a new product, service or technology gone through the practical realization stage as a result of the innovative activity. The life cycle of innovation product includes the stages of production of new product, its market promotion, market development, stabilization, transformation and etc. Enterprises engaged in the creation of innovation product carry out the following stages of the innovation process: decision-making on transition of innovative development path, development of innovation idea, development of innovative development concept, specification of main principles of innovative development, preparation of innovative development plan, realization of innovative development plan and etc.

It is suggested to include the following subindices in IPS index of technopark:

- $\quad$ effectiveness of the structure and dynamics of innovation products and services (SIPS);

- $\quad$ effectiveness of the structure and dynamics technological innovations (ESTI);

- $\quad$ level of development of innovation product marketing program (IPMP);

- $\quad$ level of commercialization of innovation products and services (CIPS);

- $\quad$ export share of innovation products and services (EIPS);

- $\quad$ import share of innovation products and services (IIPS);

- $\quad$ share of customer-oriented innovation products and services (COIPS);

- $\quad$ science intensity of innovation products and services (SIPS);

- $\quad$ resource intensity of innovation products and services (RIPS);

- $\quad$ rate of the process of promotion of innovation products and services (PIPS);

- compliance of innovation products and services with international standards (IPSI)

Considering the above mentioned symbols, the designation of IPA index can be functionally $\left(F_{8}\right)$ expressed as follows:

$I P S=F_{8}(S I P S, E S T I, I P M P, C I P S, I M X R, E I P S, I I P S, C O I P S$, SIPS, RIPS, PIPS, IPSI). 


\section{Effective management and creative results (EMC) index}

This index characterizes the level of effectiveness of management in technoparks, level of staff participation in management process and of profitability of intellectual technologies. It allows to hypothesize on the level of establishment of applicative and creative potential and the level of market promotion of creative products and services. At the same time, it also reflects the degree of boosting the efficiency of work outcomes and the level of transparency of activities.

In traditional terms, the creativity is one of the relatively sustainable characteristics of personality and specifies the creative potential and creative capacity.

The creativity process in technopark is constituted of mutually linked components and can achieve the change in environment and development of new products and services based on the creative use of the elements such as reflection, analysis, purposeful transformation and repeated organization [27].

The main outcomes of creative potential entail human capital (resources), structure (institutional) capital, social capital and cultural capital. The following can pertain to the database of creativity [28]: economic benefit of creativity, inventive activity for economic sectors, other outcomes of creative activity and etc. The main sectors covered by creative sectors are as follows: economic benefits of creative industry, the percentage of population engaged in creative industry, trade value of creative industry, economic benefits of e-trade, inventive capacity of business sectors, innovation activity under the condition of patent application, etc.

It is suggested to include the following subindices in EMC index:

- level of effectiveness of management structure (LSMS);

- level of staff participation in management processes (LSMP);

- level of improving the efficiency of decision-making (LIED);

- level of application of new and intellectual technologies in management (ANIM);

- level of profitability (LPR);

- level of stimulation of work outcomes (LSWO);

- level of improving of the transparency of activity (LITA);

- level of commercialization of scientific-research outcomes (LCSO);

- level of formation of creative potential (LFCP);

- level of formation of demand for creative products and services (FDCP);

- level of development, application and use of creative products and services (DAUC);

- level of use of new technologies in generating creative outcomes (UTCU);

- access opportunities of creative products and services to foreign markets (CPFM).

Considering the above mentioned symbols, the designation of EMC index can be functionally $\left(F_{9}\right)$ expressed as follows:

$E M C=F_{9}(L S M S, L S M P, L I E D, A N I M, L P R, L S W O, L I T A, L C S O$, LFCP, FDCP, DAUC, UTCU, CPFM).

\section{Socio-ecological development (SED) index}

This index characterizes the current level of socio-ecological development and the living standard, welfare of personnel and the opportunities of improving the work condition. At the same time, it also reflects the level of formation of green economy and the efficiency of environmental investments.

Social development policy in technoparks is a policy oriented towards the improvement of social condition of human resources. The social condition of technopark is constituted of such parameters as the living standard, material welfare and quality of life of experts. Socio-economic development considers the use of education, scientific, healthcare and cultural services and the generation of new and more favorable condition in formation of social relations [30]. The primary goal of social policy is to positively affect the current social situation. 
Ecological infrastructure encompasses the fields such as water resources, green infrastructure, waste, and the management of natural disaster risks. In technoparks, the following directions are considered as main directions of environmental policy: the application of advanced methods of sustainable development principles in order to minimize the environmental pollution and regulate its protection, efficient utilization of natural resources in order to meet the demand of current and future generations, benefit from inexhaustible energy sources and achieve energy efficiency via non-traditional methods, to assess the current situation on global environmental problems at national level, expansion of relations with international organizations, extensive use of national potential opportunities and etc [31-32].

Following subindices are suggested to be included in SED index of technopark: level of durability and sustainability of socio-economic development (DSED); level of development of the standard of living of staff (DSLS); level of raising socio-ecological quality (RSEQ); opportunities of improving the health status (OIHS); opportunities to improve welfare level (OIWL); opportunities to improve work conditions (OIWC); level of improving living standard of work staff (LSWS); level of greening the economy and efficient utilization of natural resources (GEEU); level of protection of environment against pollution (LPEP); level of preventing incurred economic loss on environment (PIEE); degree of environmental investments (DEI); degree of harmfulness of waste and technological processes (DHWT); level of impact of environmental situation on health (LIEH); level of improving the quality of education (LIQE).

Considering the above mentioned symbols, the designation of SED index can be functionally $\left(F_{10}\right)$ expressed as follows:

$$
\begin{gathered}
S E D=F_{10}(S E I D, P H T I, S E K Y, S S Y I, R S Y \dot{I}, \text { OIWC, LSWS, GEEU, LPEP, PIEE, DEI, } \\
\text { DHWT, LIEH, LIQE). }
\end{gathered}
$$

\section{Conclusion}

The system of indices, subindices and variables on the comparative assessment of the activity of technoparks are divided into various hierarchic levels. The first national level is constituted of a composite integrative index of technoparks, 2nd level by 10 indices, 3rd level by 118 subindices, and 4th level by 408 macro and micro variables. Indices and subindices at the 1st, 2nd and 3rd levels are determined based on expert assessment, and by parameters constituting the following level.

Both official statistical, external and internal indicators are included in the 4th level variables. The 4th level indicators play a role of a base for determining 3rd and 2nd level subindices by experts. In such case, absolute indicators and their precise values are used (Figure 3). The approach here is different and can be implemented in an individual manner according to each specific situation.

The composite index has a feature of "monotonic growth", given that the 1 st level indices and 2nd level subindices take values within $[0,100]$ interval. That is, the growth of figures indicates the improvement of environment, whereas the reduction in values denotes the deterioration.

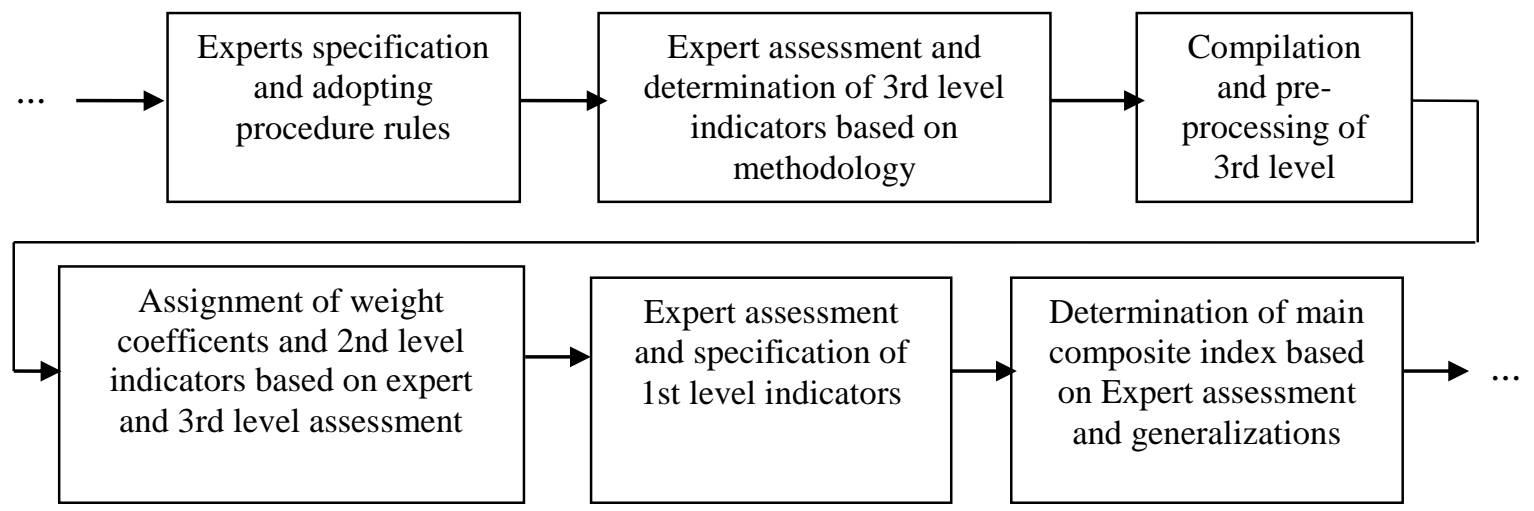

Figure 3. Successive stages of formation of specification of indices and indicators of technoparks 
The system of indicators related to independent and comparative assessment of technoparks' activity addresses the goals posed during the process of assessment of technoparks' activity at both regional and international levels extensively. The indicators system suggested for such comparative assessment meets the contemporary demands as a successful model for a separate assessment of the activity of technoparks, which currently function and to be established in future.

Several indices and subindices were suggested for the first time for the comparative analysis of the activity of technoparks. At the same time, the authors do not claim the completeness of the system of indices, and hence, the system is developed as an open system that will be enriched with further amendments.

\section{References}

1. The Law of the Republic of Azerbaijan on Special Economic Zones. Baku, 14 April 2009, http://www.meclis.gov.az

2. The Decree of the President of the Republic of Azerbaijan on the approval of the "National Strategy for information society development in the Republic of Azerbaijan for 2014-2020 years", 2 April 2014, http://www.president.az.

3. "Azerbaijan - 2020: Vision for Future" Development Concept. Baku, 29 December 2012, http://www.president.az.

4. The Decree of the President of the Republic of Azerbaijan on the establishment of High Technologies Park, 5 November 2012, http://www.president.az

5. Aliyev A.G. Issues of development of indicators system on the assessment of the level of development of Information society // Information society problems, 2014, №1, pp. 65-74.

6. Silicon Valley Index, http://www.siliconvalleyindicators.org

7. David N. E. Rowe BSc MBA. Setting up, Managing and Evaluating EU Science and Technology parks. An advice and guidance report on good practice. Luxembourg: Publications Office of the European Union. 2014, 211 p.

8. Andreevna M.A. The Balanced Scorecard for Estimation of Science and Technology Parks // World Applied Sciences Journal, 2013, 25(5), pp.720-727.

9. Barinova V.A., Maltseva A.A., Sorokina A.V., Yeremkin V.A. Attitudes to the efficiency assessment of functioning of buildings of innovative infrastructure in Russian Federation // Innovations, 2014, №3(185), pp. 42- 51 .

10. Borisov V.V. Information provision of innovation activity in company // Problems of economy and law, 2012, №10, pp.101-105.

11. Alguliyev R.M., Aliyev A.G., Shahverdiyeva R.O. Development of information support systems for management of innovative structures / The 8th IEEE International Conference on Application of Information and Communication Technologies (AICT2014), Astana, 2014. pp. 378-382.

12. Alekseevich B.M. Formation of innovation environment of modern technoparks. Abstract of dissertation for obtaining PhD degree in Economics, Moscow, 2013, http://www.economylib.com/formirovanie-innovatsionnoy-sredy-sovremennyh-tehnoparkov.

13. Yemelyanov S.G., Borisoglebskaya L.N., Maltseva A.A. formation of resident strategy of technopark as a mechanism of building favorable business-environment of the region // Economics, Law and Sociology Herald, 2010, №3, pp.32-39

14. Ignatov Y.S. Theoretical aspects of the genesis of business environment // Problems of modern economy, 2011, №1(37), http://www.m-economy.ru

15. Velichko V.V. Modeling the financial-economic activity of Kuzbass technopark // Herald of RA of Natural Sciences, 2009, №2, pp. 28-30.

16. Ahmedovna T.M. Formation of perspectives of development of financing system of innovative-active organizations, abstract of dissertation obtaining $\mathrm{PhD}$ degree in Economics, Moscow, 2013, http://www.fa.ru/dep/ods/autorefs/Documents/2013_11 
17. Faizrahmanova G.R., Kozlova N.N. The System of Indicators of Enterprise's Innovative Activity // Asian Social Science, 2015, №11, vol. 11, pp.183-187.

18. Neznakina Y.L., Veretenova M.C. Assessment method of integral indicators of innovative activity of enterprise // Innovations, 2012, №2(160), pp.93-97.

19. Trophimov O.V. Main directions of transformation in the functions of organization within the strategy of innovation strategy // Creative economy, 2010, №4, pp.17-21.

20. Kotsubinsky V.A., Yeremkin V.A.. Measuring the level of innovative development: world practice and Russian experience, Moscow, 2014, 192 pp.

21. Shamil M.V., Khakimov A.K. Innovative potential as a framework of innovative strategy for enterprise development / International Conference on Applied Economics, ICOAE 2015, Russia, pp.716-721.

22. Kharchenko E., Alpeeva E., Ovcharova O. Innovative Potential of Russian Regions: Methodological Aspects of Analysis and Development Trends / International Conference on Applied Economics (ICOAE), 2014, pp. 313-319.

23. European Commission, Directorate-General for Regional Policy. Evaluation of Innovation Activities. Guidance on methods and practices. European Union, 2012, 64 p.

24. Ferguson D.L., Fernández R.E. The Role of the University in the innovation ecosystem, and Implications for science cities and science parks: A human resource development approach // WTR, 2015, vol.4, pp.132-143.

25. Marshalkina T.V. Key differences of projects on creating innovative products // Problems of modern economy, 2014, №4(52), pp.28-31.

26. Mutanov G. Methods and Mathematical Models of Innovation Project Appraisal // Journal Mathematical Methods and Models in Economic Planning, Management and Budgeting, 2015, pp. 131-194

27. Kirilyuk O.M., Legchilina Y.Y. Assessment of intellectual-creative resources in the system of organization management // Fundamental research, 2015, №7, pp.595-600.

28. Wasim M.U. Factors for science park planning, WTR, 2014, vol.3, pp.97-108.

29. Wenbo L. Comprehensive evaluation research on circular economic performance of ecoindustrial parks // Energy Procedia, 2011, vol. 5, pp.1682-1688.

30. Musayev A.F. Social policy and economic development // Tax Journal of Azerbaijan, 2013, №1, pp. 67-86.

31. Shpak N.A. Modern science parks and industrial parks as instruments of economic transition of the region to "green economy" principles // SPLA News, 2014, vol. 208, pp. 267- 275.

32. Chen H.S., Chien Li.H., Hsieh T. A study of assessment indicators for environmental sustainable development of science parks in Taiwan // Journal Environmental Monitoring and Assessment, 2013, vol. 185, Issue 8, pp. 7001-7012. 